\title{
Characteristic analysis and prevention strategy of trench collapse accidents in the U.S., 1995-2020
}

\author{
Özge Akboğa Kale®1
}

1 Izmir Demokrasi University, Department of Civil Engineering, Esmirna (Turkey), ozge.akbogakale@idu.edu.tr

*Correspondence: ozge.akbogakale@idu.edu.tr

Received: 26.04.2021; Accepted: 13.12.2021; Published: 31.12.2021

Citation: Akboğa Kale, Ö. (2021). Characteristic analysis and prevention strategy of trench collapse accidents in the U.S., 1995-2020. Revista de la Construcción. Journal of Construction, 20(3), 617-628. https://doi.org/10.7764/RDLC.20.3.617.

\begin{abstract}
Statistics show that many workers have lost their lives because of trench collapse although the dangers of trenching are well known and defined. Thus, the question of "why" should be asked again. The most comprehensive data set in the literature has been created to determine the reason for the recurrence of accidents even though the risks are known. A total of 723 accidents caused by trench collapse in the last 25 years were selected from the Occupational Safety and Health Administration's database. Variables were created using accident summaries, and the frequency distribution of the categories was interpreted. Results showed that these accidents have a high frequency and a high severity level (58.1\% fatalities). The main reason for a half of the accidents was the lack of protective systems (49.7\%). A total of 2596 violations including four main categories were detected for 723 accident reports. Employers paid approximately 23 million in penalties. The investigated accidents showed that trench collapse accidents are rarely survivable but can be completely prevented if necessary precautions are taken.
\end{abstract}

Keywords: construction industry; accident investigation; excavation; trench collapse; cave-in.

\section{Introduction}

Excavation work, which is one of the most basic jobs in the construction field, generally means work that involves the removal of soil or rock from a site to form an open face, hole, or cavity using tools, machinery, or explosives. Almost no construction work is completed without excavation. Trench collapses and excavation cave-ins are few of the most fatal occupational accidents in construction (OSHA, 2020). The data on occupational accidents can be obtained from several agencies, such as the Occupational Safety and Health Administration (OSHA), the Bureau of Labor and Statistics (BLS), the National Institute for Occupational Safety and Health (NIOSH), and the National Safety Council. The seriousness and importance of the issue are revealed when the alarming statistics published by these agencies on the occupational fatalities in the excavation works is examined (Table 1).

OSHA (2002) indicated that the fatality rate for excavation work is $112 \%$ higher than the rate for general construction (Arboleda and Abraham, 2004). According to The Center for Construction Research and Training (CPWR), 34 workers passed away in 2011-2014 and 29 in 2015-2016 because of trench collapses (Ruttenberg et al., 2019). Current trench collapses and fatalities seem to continue in alarming numbers. Schriver and Schoenbaum (2003) stated that fatal trench collapses inspected by OSHA in 1991-2001 accounted for 4.7\% of the fatal construction events. According to statistics, an average of $81.6 \%$ of 
trench collapse accidents occurred in the construction industry. Trench fatalities in the construction industry are presented in Figure 1.

Table 1. Number of fatalities resulting from trenching and excavation.

\begin{tabular}{cccc}
\hline Agency & Time range & Identified cases & Source \\
\hline OSHA & $1985-1989$ & 239 fatalities & Culver et al., 1990 \\
BLS & $1992-1999$ & 54 fatalities per year & McCann, 2006 \\
BLS & $1992-2001$ & 542 fatalities & MMWR, 2004 \\
NIOSH & $1992-2006$ & 759 fatalities & Ruttenberg et al. 2019 \\
OSHA & 1998 & 33 fatalities & Boom, 1999 \\
BLS & $2000-2006$ & 271 fatalities & Elcosh, 2020 \\
BLS & $2000-2009$ & 350 fatalities & BLS, 2010 \\
BLS & $2003-2005$ & 159 fatalities & CPWR, 2007 \\
BLS & $2008-2017$ & 180 fatalities & BLS, 2019 \\
\hline
\end{tabular}

The fact that the accidents occurring in excavation works are frequent and severe has led researchers to work on this issue. Rampuri (2019) aimed to identify the potential sources of harm during excavation and trenching activity by searching the literature. Thwala et al. (2018) employed the Delphi method by using questionnaires to assess health and safety risks associated with excavation cave-in in Cape Coast Metropolis. Flynn and Sampson (2012) aimed understand the existing trenching practices and to increase the effectiveness of safety training by using a qualitative approach. Lan and Daigle (2009) reviewed regulations and guides in the excavation and trench work of several countries. Jannadi (2007) aimed to explain the potential risk and present safety precautions of trenching works in Saudi Arabia by surveying contractors. Hinze (2005) analyzed 151 responses collected from the contractor members of the National Utility Contractors Association to provide an overview of the status of the use of trench boxes. Lee (2003) measured productivity loss from an accident in terms of a delay in utility trenching operations. Suruda et al. (2002) conducted a study to examine the impact of the revised rule on fatal injuries in the construction industry from trench cave-in. Table 2 summarized the literature mainly in 1988-2006 that focused on fatal accidents caused by trench collapses. Trench collapse fatalities in 2016, which have more than doubled than that in 2015, is concerning. A worker in a collapsed trench is more likely to be killed than injured (ASH, 2020).

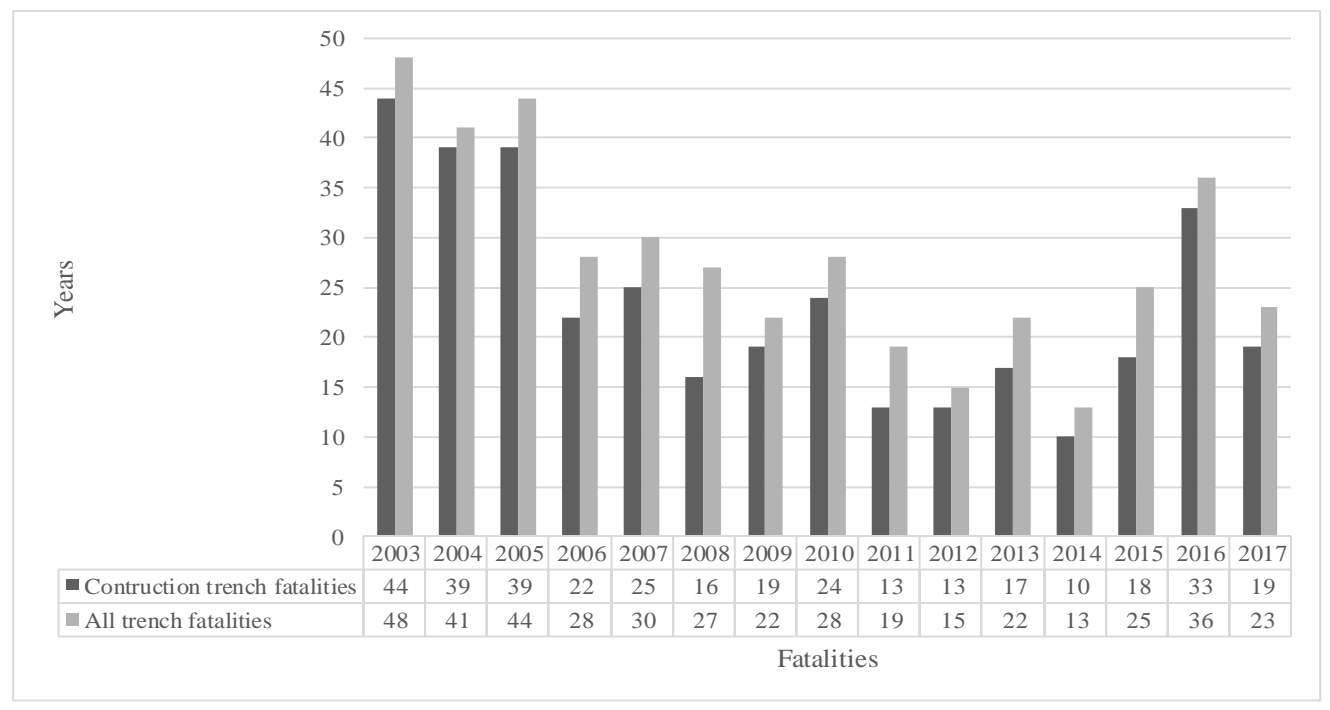

Figure 1. Trench fatalities, 2003-2017 (Source Census of Fatal Occupational Injuries-CFOI)

To reduce occupational accidents that have occurred in excavation works, which often result in loss of life, the hazards of the process must first be well defined. Excavation works carry many dangers and risks because of the nature of the work and environmental conditions. These dangers and risks include trench collapse; falling into an excavation area; flood or water accumulation; confined spaces; heavy and mobile equipment; excavation vehicles, load, or equipment falling on the workers; 
oxygen deficiency; toxic, flammable, and explosive gases; entries and exits to the excavation; underground cables; and hazards related to material handling (e.g., lifting, struck by, and crushed between) (CCOHS, 2016).

Table 2. Summary of selected reports on trench collapse related fatalities in construction.

\begin{tabular}{|c|c|c|}
\hline Author(s) & Scope and data source & Findings/insights \\
\hline \multirow{2}{*}{$\begin{array}{l}\text { Plog et al., } \\
2006\end{array}$} & \multirow{2}{*}{$\begin{array}{l}\text { Detailed data of serious or fatal trenching- } \\
\text { related injuries } \\
162 \text { cases from Cal/OSHA, 1993-2004 }\end{array}$} & Public awareness of trench safety should be increased. \\
\hline & & $\begin{array}{l}\text { A training module for competent persons that teaches how to } \\
\text { conduct effective tailgate trainings for trenching crew workers } \\
\text { should be developed. }\end{array}$ \\
\hline \multirow[t]{2}{*}{$\begin{array}{l}\text { McCann, } \\
2006\end{array}$} & \multirow{2}{*}{$\begin{array}{l}\text { Heavy equipment- and truck-related deaths } \\
\text { in the excavation work industry in } \\
\text { construction. } \\
253 \text { deaths from BLS, 1992-2002 }\end{array}$} & $\begin{array}{l}\text { Heavy equipment operators and construction laborers made up } \\
63 \% \text { of the heavy equipment- and truck-related deaths. }\end{array}$ \\
\hline & & Rollovers were the main cause of death. \\
\hline \multirow[t]{2}{*}{$\begin{array}{l}\text { Deatherage } \\
\text { et al, } 2004\end{array}$} & \multirow{2}{*}{$\begin{array}{l}\text { Physical conditions and organizational } \\
\text { factors associated with fatal trench } \\
\text { collapses. } \\
44 \text { deaths from OSHA, 1997-1999 }\end{array}$} & $\begin{array}{l}\text { Improper protection of the excavation site was the leading } \\
\text { fatality cause. }\end{array}$ \\
\hline & & No training had been provided for trenching. \\
\hline \multirow{3}{*}{$\begin{array}{l}\text { Arboleda } \\
\text { and } \\
\text { Abraham, } \\
2004\end{array}$} & \multirow{3}{*}{$\begin{array}{l}\text { Analyzing the fatality reports and finding } \\
\text { the major relationships between the } \\
\text { "how" and the "why" of trenching } \\
\text { fatalities } \\
296 \text { deaths from OSHA, 1997-2001 }\end{array}$} & In $94 \%$ of cave-ins, no protective systems in place. \\
\hline & & $\begin{array}{l}84 \% \text { of companies had received at least one prior OSHA } \\
\text { citation. }\end{array}$ \\
\hline & & $\begin{array}{l}\text { Identified need for trench protective systems, proper job } \\
\text { planning, and compliance with the OSHA standard to help } \\
\text { prevent deaths. }\end{array}$ \\
\hline \multirow[t]{2}{*}{$\begin{array}{l}\text { Wagner, } \\
2004\end{array}$} & \multirow{2}{*}{$\begin{array}{l}\text { Identification of contributed factors of the } \\
\text { fatalities to determine the causation of } \\
\text { collapses. } \\
44 \text { deaths from OSHA, 1997-1999 }\end{array}$} & $\begin{array}{l}\text { Many trenches without any type of protective devices being } \\
\text { used. }\end{array}$ \\
\hline & & $\begin{array}{l}\text { Fatal events might have been prevented if there was compliance } \\
\text { with OSHA regulations for protective devices in the trenches, } \\
\text { training of employees, and having an OSHA trained competent } \\
\text { person on site. }\end{array}$ \\
\hline $\begin{array}{l}\text { Lew et al., } \\
2002\end{array}$ & $\begin{array}{l}\text { Discussion the role of the competent } \\
\text { person in excavation safety and analyzing } \\
\text { characteristics of accidents } \\
52 \text { deaths from NIOSH, } 1985-2000\end{array}$ & $\begin{array}{l}\text { Two key observations from the initial review of records point to } \\
\text { the need for a competent person at the work site and effective } \\
\text { worker training prior to the commencement of construction } \\
\text { operations. }\end{array}$ \\
\hline \multirow[t]{3}{*}{$\begin{array}{l}\text { Suruda et al., } \\
1988\end{array}$} & \multirow{3}{*}{$\begin{array}{l}\text { Providing information on cave-in fatalities } \\
\text { that would call attention to the problem and } \\
\text { would support a revision of OSHA } \\
\text { standards for trenches. } \\
306 \text { deaths from OSHA, 1974-1986 }\end{array}$} & $\begin{array}{l}\text { Most of the deaths occurred in shallow trenches while digging } \\
\text { sewer lines and were caused by falling to shore or brace the } \\
\text { walls of the trench. }\end{array}$ \\
\hline & & $\begin{array}{l}\text { The risk of cave-in death was higher in young workers and } \\
\text { those in small firms. }\end{array}$ \\
\hline & & Only $12 \%$ of the deaths were in unionized companies. \\
\hline
\end{tabular}

Among these sources of danger, trench collapse causes the most work accidents, deaths, and injuries. It occurs in the form of the soil being thawed and loosened at the edge of the excavated area because of various reasons during work and the workers suddenly slipping or falling into the excavated area. Various studies have shown that the most common cause (71\%) of trench related fatalities are trench collapses (Hinze et al., 1998).

Therefore, this study is conducted to understand the causes of trench collapse accidents associated with trenching operations through the analysis of 723 occupational accidents that occurred because of trench collapse in the U.S. between 1995 and 2020 and to develop intervention strategies to identify the causes of trench collapse accidents and review of the literature. Consequently, the findings of this study will give an opportunity to provide further precautions for preventing future accidents. It is expected that the findings obtained in the study will guide the companies in the field of excavation, guide the occupational safety departments of the companies, inform the occupational safety experts and inspire the researchers.

\section{Data acquisition}

OSHA was created to maintain a reporting and recordkeeping system to monitor job-related injuries and illnesses. Data used in this study were acquired from OSHA accident reports commonly used in construction safety studies in the U.S. and 
in other countries (McCann, 2006; Hinze et. al., 2005). The Accident Investigation Search enables searching the OSHA Integrated Management Information System enforcement database for accident abstracts that contain specified terms. This database contains abstracts dating back to 1984 and injury data dating back to 1972. Fatality and catastrophe investigation summaries provide a complete description of the incident, generally including events leading to the incident and causal factors.

This study focuses on accidents due to the trench collapse in the last 25 years. Standard Industrial Classification (SIC) codes were taken as a basis while creating the data set. SIC codes are four-digit numerical codes assigned by the U.S. government to institutions for identifying the primary business of the establishment. In the study, Division C: Construction was taken into consideration with Major Groups 15, 16, and 17 (Table 3). Finally, 723 cases with non-fatal and fatal consequences satisfied the criteria to establish the accidents caused by the trench collapse in 1995-2020.

Year of accident, end use and cost of project that accident occurred, degree of injury, type of injury, cause of accident, occupation and union status of worker, violations and penalties were examined as variables. By conducting a detailed examination of the abstracts, additional information, such as soil type, soil condition, the depth of the trench and the unsafe act, was extracted from the reports.

Table 3. Variation of Standard Industrial Classification (SIC) codes.

\begin{tabular}{|c|c|c|c|c|}
\hline Division & Major Group & Industry group & Subgroup & $\mathrm{n}$ \\
\hline \multirow{12}{*}{ 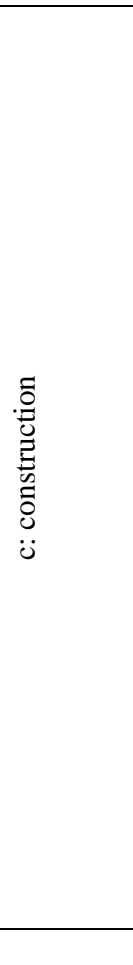 } & \multirow{2}{*}{$\begin{array}{l}\text { 15: Building } \\
\text { construction } \\
\text { general } \\
\text { contractors } \\
\text { and operative } \\
\text { builders }\end{array}$} & $\begin{array}{l}\text { 152: General building contractors- } \\
\text { residential }\end{array}$ & $\begin{array}{l}1521 \text { general contractors-single-family houses } \\
1522 \text { general contractors-residential buildings, other than } \\
\text { single-family }\end{array}$ & $\begin{array}{c}19 \\
6\end{array}$ \\
\hline & & $\begin{array}{l}\text { 154: General building contractors- } \\
\text { non-residential }\end{array}$ & $\begin{array}{l}1541 \text { general contractors-industrial buildings and } \\
\text { warehouses } \\
1542 \text { general contractors-non-residential buildings, other } \\
\text { than industrial buildings and warehouses }\end{array}$ & 30 \\
\hline & \multirow{2}{*}{$\begin{array}{l}\text { 16: Heavy } \\
\text { construction } \\
\text { other than } \\
\text { building } \\
\text { construction } \\
\text { contractors }\end{array}$} & $\begin{array}{l}\text { 161: Highway and street construction, } \\
\text { except }\end{array}$ & $\begin{array}{l}1611 \text { highway and street construction, except elevated } \\
\text { highways }\end{array}$ & 19 \\
\hline & & $\begin{array}{l}\text { 162: Heavy construction, except } \\
\text { highway and street }\end{array}$ & $\begin{array}{l}1623 \text { water, sewer, pipeline, and communications and } \\
\text { power line construction } \\
1629 \text { heavy construction, not elsewhere classified }\end{array}$ & 263 \\
\hline & \multirow{8}{*}{$\begin{array}{l}\text { 17: } \\
\text { Construction } \\
\text { special trade } \\
\text { contractors }\end{array}$} & $\begin{array}{l}\text { 171: Plumbing, heating and air- } \\
\text { conditioning }\end{array}$ & 1711 plumbing, heating and air-conditioning & 85 \\
\hline & & 172: Painting and paper hanging & 1721 painting and paper hanging & 1 \\
\hline & & 173: Electrical work & 1731 electrical work & 13 \\
\hline & & $\begin{array}{l}\text { 174: Masonry, stonework, tile setting, } \\
\text { and plastering }\end{array}$ & 1741 masonry, stone setting, and other stonework & 4 \\
\hline & & $\begin{array}{l}\text { 176: Roofing, siding, and sheet metal } \\
\text { work }\end{array}$ & 1761 roofing, siding, and sheet metal work & 1 \\
\hline & & 177: Concrete work & 1771 concrete work & 18 \\
\hline & & $\begin{array}{l}\text { 179: Miscellaneous special trade } \\
\text { contractors }\end{array}$ & $\begin{array}{l}1794 \text { excavation work } \\
1795 \text { wrecking and demolition work } \\
1799 \text { special trade contractors, not elsewhere classified }\end{array}$ & $\begin{array}{c}185 \\
4 \\
13 \\
\end{array}$ \\
\hline & & & total & 723 \\
\hline
\end{tabular}

\section{Results discussion}

A total of 723 summaries of accident investigations were analyzed to identify the causes of accidents specifically related to trench collapse in 1995-2020. The distribution of accidents caused by trenches per year is presented in Figure 2. April and June are the top two months have the highest frequency of accidents, followed by October. According to Hinze and Bren (1997), the presence of more subsurface water in the ground in October may perhaps explain the high incidence in October. Lew et al (2002) also found that October was the month with the highest incidence (16\%) of accidents (1996-1997). 
Excavations are indispensable for the construction industry. Many types of excavations exist depending on the construction site and the nature of the work. Open excavations; undergrounds; dams; hydroelectric power plants; road; tunnels; art structures; stripping, cleaning, and shaping excavations; and trench excavations are some of these excavation types. For this reason, saying that excavation works are a part of the process regardless of the end use is possible. Table 4 reveals how diverse project end uses are. The projects on which trench work is carried out is mostly single-family or duplex dwelling (26.3\%), pipeline (16.6\%), excavation and landfill (11.5\%), and commercial building (11.5\%). A great majority of the victims worked on a new project or a new addition to an existing project (65.8\%). Approximately $17.9 \%$ of victims worked for maintenance or repair. Almost all workers $(98.1 \%)$ who had an accident work in private ownership.

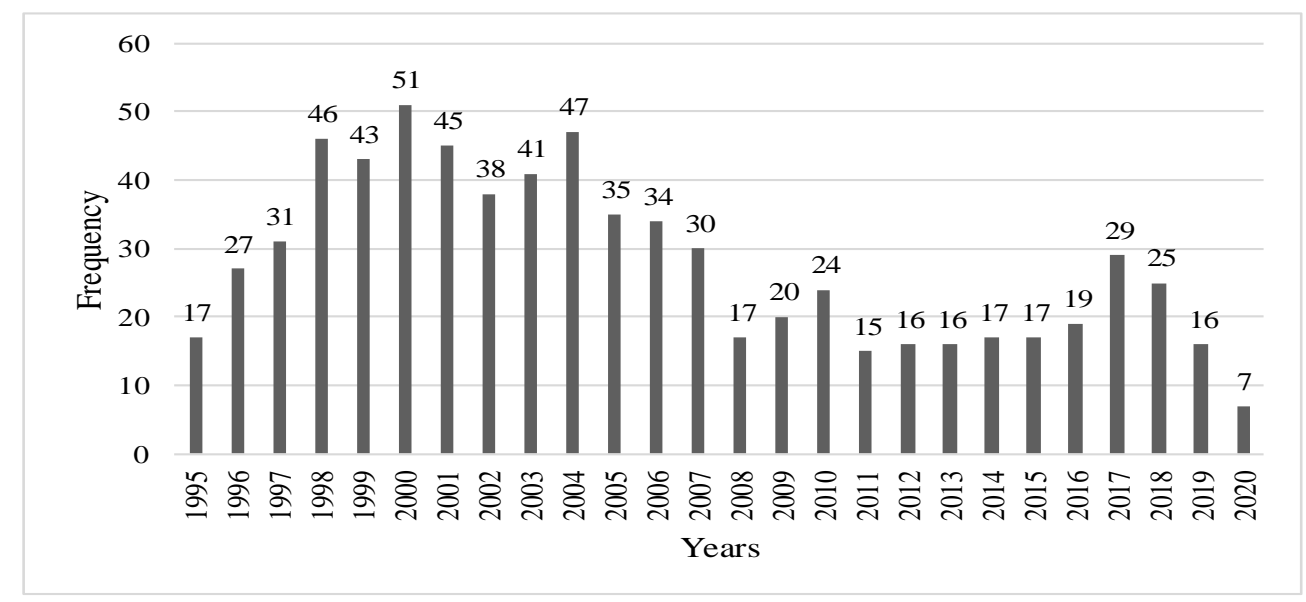

Figure 2. Distribution of accidents by years.

Approximately $28.4 \%$ of the injuries or fatalities due to trench collapse occurred in projects that cost under US\$50000. According to the results, $46.1 \%$ of the accidents occurred in projects that cost less than US $\$ 250000$ (Figure 3). Small and medium contractor companies may give less importance to occupational safety and health measures, may not necessarily address the safety standards adequately, or may have insufficient budget to provide safety precautions (Forteza et al, 2020; Arboleda and Abraham, 2004).

Table 4. Distribution of end use.

\begin{tabular}{llcc}
\hline Variable & Categories & Frequency & Valid percent \\
\hline & Single family or duplex dwelling & 185 & 26.3 \\
& Pipeline & 117 & 16.6 \\
& Excavation, landfill & 81 & 11.5 \\
& Commercial building & 81 & 11.5 \\
& Sewer/water treatment & 77 & 10.9 \\
& Highway, road, street & 48 & 6.8 \\
& Other building & 36 & 5.1 \\
& Multi-family dwelling & 33 & 4.7 \\
& Other heavy construction & 31 & 4.4 \\
& Powerline, transmission line & 5 & 0.7 \\
& Manufacturing plant & 4 & 0.6 \\
& Bridge & 3 & 0.4 \\
\hline
\end{tabular}

More than half of the accidents (58.1\%) resulted in a loss of life (Table 5). Examining the type of injury caused by accident, asphyxia (34.4\%) and fractures (23.0\%) were the top two types of injuries. Almost all the accidents caused by asphyxia $(98.0 \%)$ resulted in death when the distribution of the degree of injury according to injury types is examined. Fracture injuries (72.9\%) resulted in hospitalized injuries (Table 6). Some of the information about the cause of the accident variable was not available in a small part of the dataset $(9.5 \%)$. However, among the provided information, trenching and installing pipes (51.7\%) and excavating (31.5\%) were two prominent causes (Table 7). More than half of the workers had fatal injuries during 
excavation (59.7\%) and trenching and installing pipe works (58.3\%). In other words, one of two employees who carried out these two kinds of work within the analyzed data set died.

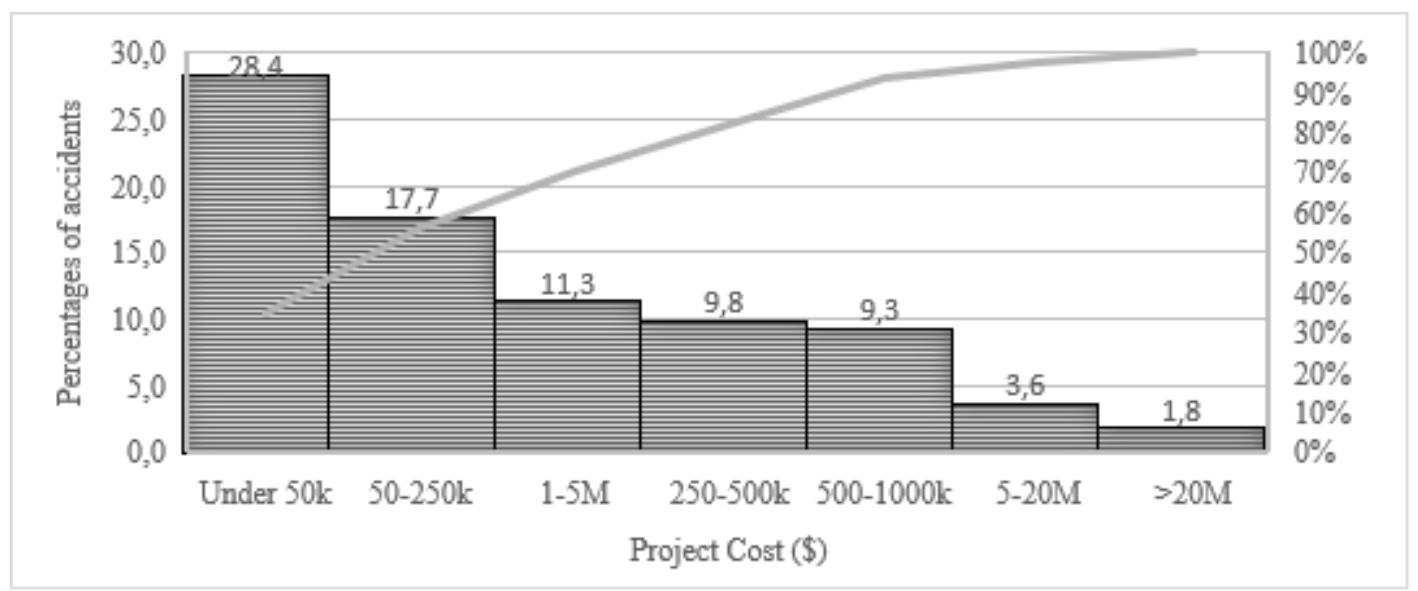

Figure 3. Project cost.

Table 5. Accident Characteristics.

\begin{tabular}{llcc}
\hline Variable & Categories & Frequency & Percent \\
\hline \multirow{3}{*}{ Degree of injury } & Fatality & 420 & 58.1 \\
& Hospitalized injury & 233 & 32.2 \\
& Non-Hospitalized injury & 70 & 9.7 \\
\hline
\end{tabular}

Table 6. Contingency table-degree of injury vs. type of injury.

\begin{tabular}{lcccc}
\hline \multirow{2}{*}{ Type of injury } & \multicolumn{3}{c}{ Degree of Injury } & Total \\
\cline { 2 - 5 } & Fatality & $\begin{array}{c}\text { Hospitalized } \\
\text { injury }\end{array}$ & $\begin{array}{c}\text { Non-hospitalized } \\
\text { injury }\end{array}$ \\
\hline Asphyxia & $244(98.0 \%)$ & $5(2.0 \%)$ & - & $249(100.0 \%)$ \\
Fractures & $38(22.9 \%)$ & $121(72.9 \%)$ & $7(4.2 \%)$ & $166(100.0 \%)$ \\
Other & $105(68.2 \%)$ & $37(24.0 \%)$ & $12(7.8 \%)$ & $154(100.0 \%)$ \\
Bruises/contusions/abrasions & $19(18.8 \%)$ & $45(44.6 \%)$ & $37(36.6 \%)$ & $101(100.0 \%)$ \\
Sprain/strain & - & $9(50.0 \%)$ & $9(50.0 \%)$ & $18(100.0 \%)$ \\
Concussion & $7(43.8 \%)$ & $6(37.5 \%)$ & $3(18.8 \%)$ & $16(100.0 \%)$ \\
Dislocation & $1(12.5 \%)$ & $5(62.5 \%)$ & $2(25.0 \%)$ & $8(100.0 \%)$ \\
Cuts/lacerations & $5(71.4 \%)$ & $2(28.6 \%)$ & - & $7(100.0 \%)$ \\
Amputation & $1(33.3 \%)$ & $2(66.7 \%)$ & - & $3(100.0 \%)$ \\
Puncture & - & $1(100.0 \%)$ & - & $1(100.0 \%)$ \\
Total & $420(58.1 \%)$ & $233(32.2 \%)$ & $70(9.7 \%)$ & $723(100.0 \%)$ \\
\hline
\end{tabular}

Knowing the characteristics of employees who had work accidents and determining what characteristics do individuals prone to accidents have are important. The first thing to draw attention to is that the occupation of the victim was not reported in $37.3 \%$ of the cases (Table 8). The majority of the victims were construction laborers (35.3\%). A similar result was obtained in OSHA's 2003 investigation. According to the investigation, most of the workers who have lost their lives were construction laborers, followed by plumbers and pipe fitters (Laborer's Health and Safety Fund of North America, 2020). The CFOI data from 2011 through 2014 showed that construction laborers were the most likely to die in trenches, but plumbers and pipelayers also suffer losses (Ruttenberg, 2019). Hinze et al. (1998) indicated that plumbers and pipefitters are most often involved in accidents resulting from trench cave-ins. Approximately $91.7 \%$ of the victims were non-union. Lew et al. (2002) also found that most of the workers (98\%) were non-union. It was found that employees in unions compared to non-unionized employees are more likely to self-report injuries and illnesses in the workplace and follow through with filing workers' compensation claims (Le et al., 2021). This also may be attributed to those in unions working more dangerous and laborious jobs (e.g., construction, steel work), working in larger industries, being educated by their union about their employee rights, and their 
union's contributions to workplace safety culture where self-reporting injuries is encouraged (Fenn and Ashby, 2004; Gillen et al., 2002; Goldenhar et al., 2003).

Table 7. Contingency table-degree of injury vs. cause.

\begin{tabular}{lcccc}
\hline & Degree of injury & & \\
Cause & Fatality & $\begin{array}{c}\text { Hospitalized } \\
\text { injury }\end{array}$ & $\begin{array}{c}\text { Non-hospitalized } \\
\text { injury }\end{array}$ & Total \\
\hline Trenching, installing pipe & $197(58.3 \%)$ & $113(33.4 \%)$ & $28(8.3 \%)$ & $338(100.0 \%)$ \\
Excavation & $123(59.7 \%)$ & $56(27.2 \%)$ & $27(13.1 \%)$ & $206(100.0 \%)$ \\
Installing underground plumbing conduit & $17(39.5 \%)$ & $23(53.5 \%)$ & $3(7.0 \%)$ & $43(100.0 \%)$ \\
Installing plumbing, lighting fixtures & $6(50.0 \%)$ & $1(8.3 \%)$ & $5(41.7 \%)$ & $12(100.0 \%)$ \\
Installing culverts and incidental drainage & $6(50.0 \%)$ & $5(41.7 \%)$ & $1(8.3 \%)$ & $12(100.0 \%)$ \\
Waterproofing & $3(33.3 \%)$ & $5(55.6 \%)$ & $1(11.1 \%)$ & $9(100.0 \%)$ \\
Backfilling and compacting & $5(83.3 \%)$ & $1(16.7 \%)$ & - & $6(100.0 \%)$ \\
Site grading and rock removal & $3(60.0 \%)$ & $2(40.0 \%)$ & - & $5(100.0 \%)$ \\
Other activities-post decking detail work & $2(50.0 \%)$ & $2(50.0 \%)$ & - & $4(100.0 \%)$ \\
Landscaping & $4(100.0 \%)$ & - & - & $4(100.0 \%)$ \\
Pouring concrete foundations and walls & $1(25.0 \%)$ & $1(25.0 \%)$ & $2(50.0 \%)$ & $4(100.0 \%)$ \\
Installing equipment (HVAC and other) & $1(33.3 \%)$ & $1(33.3 \%)$ & $1(33.3)$ & $3(100.0 \%)$ \\
Steel works & $1(50.0 \%)$ & - & $1(50.0 \%)$ & $2(100.0 \%)$ \\
Pile driving & $1(50.0 \%)$ & $1(50.0 \%)$ & - & $2(100.0 \%)$ \\
Forming & - & $2(100.0 \%)$ & - & $2(100.0 \%)$ \\
Exterior carpentry & $1(50.0 \%)$ & $1(50.0 \%)$ & - & $2(100.0 \%)$ \\
\hline Total & $371(56.7 \%)$ & $214(32.7 \%)$ & $69(10.6 \%)$ & $654(100.0 \%)$ \\
\hline
\end{tabular}

Table 8. Worker characteristics.

\begin{tabular}{llcc}
\hline Variables & Categories & Frequency & Percent \\
\hline \multirow{5}{*}{ Occupation } & Occupation not reported & 270 & 37.3 \\
& Construction laborer & 255 & 35.3 \\
& Plumbers, pipe fitters and steamfitters & 59 & 8.2 \\
& Excavating and loading machine operators & 33 & 4.6 \\
& Construction trades n.e.c. & 30 & 4.1 \\
& Supervisors & 24 & 3.3 \\
& Laborers, except construction & 15 & 2.1 \\
& Helpers, construction trades & 13 & 1.8 \\
& Pipelayer & 9 & 1.2 \\
& Carpenter & 5 & 0.7 \\
& Electricians & 5 & 0.7 \\
& Welders, cutters, and metal workers & 3 & 0.4 \\
& Concrete and terrazzo finishers & 2 & 0.3 \\
\hline \multirow{2}{*}{ Union status } & Union & 60 & 8.3 \\
& Non-union & 663 & 91.7 \\
\hline
\end{tabular}

The main reason for half of the accidents was a lack of protective systems (49.7\%) (Table 9). A few examples taken from accident reports highlight the importance of the issue. As understood from the accident summaries, the main root cause of the accidents is the lack of protective systems.

...The investigation findings included unsupported and unprotected underground installations; water accumulation; lack of a competent person performing daily inspections; spoil piles not positioned at least 2 feet from the excavation edges; lack of sloping or use of a protective system; lack of a hazard communication program; and lack of Global Harmonized System training... 
...There was no protective system in place to protect workers from collapse hazards, no safe egress in place, no provision for dealing with water accumulation in the trench, inadequate control of heavy equipment location in regard to the top edge of the trench, and inadequate inspection of trench conditions...

...In addition to the lack of any protective system, it was determined that the spoil pile was left at the edge of the trench with no safe route of egress from the trench. Employees were not required to wear protection while in the trench. There was also no competent person on site. Their employer did not have a safety program and no training was provided to the employees...

The lack of a protective system was the leading cause of trench-related fatalities in a review of OSHA inspections (Deatherage et al., 2004). Québec Occupational Health and Safety Board (CSST) analyzed 44 serious and fatal accident reports that occurred in 1974-2008 and indicated that no shoring or inappropriate shoring was used in 33 of the 44 worksites (Lan and Daigle, 2009). OSHA's 2003 investigation also indicated that the main reason trenches collapse is that they are not properly protected by the protection systems such as shoring. According to the investigation, protective systems were properly employed in only $24 \%$ of the trenches. In the remainder, protective systems were improperly used (24\%), available but not in use (12\%), or simply unavailable (64\%) (Laborer's Health and Safety Fund of North America, 2020). NIOSH also concluded in 2011 that "Lack of a protective system (such as shoring, shields, or sloping) was the leading cause" of six trench cave-ins (Ruttenberg, 2019).

Table 9. Unsafe act.

\begin{tabular}{llcc}
\hline Variable & Categories & Frequency & Percent \\
\hline & Lack of protective system & 359 & 49.7 \\
& Unidentified & 252 & 34.9 \\
& Unsafe method or sequencing & 58 & 8.0 \\
Unsafe act & Unsafe site conditions & 25 & 3.5 \\
& Poor attitude toward safety & 17 & 2.4 \\
& Deficient enforcement of safety & 8 & 1.1 \\
& Not using provided safety equipment & 4 & 0.6 \\
\hline
\end{tabular}

Information on the depth of the trench was available for 479 of 723 accidents. The depth of the excavations the accident occurred was investigated (Figure 4). According to the findings, $35.9 \%$ of the accidents occurred in excavations with a depth of more than $10.6 \mathrm{ft}$. Moreover, some limited findings were obtained about excavation characteristics (Table 10).

Table 10. Excavation characteristics.

\begin{tabular}{llcc}
\hline Variables & Categories & Frequency & Percent \\
\hline \multirow{3}{*}{ Soil type } & Type A & 4 & 7.8 \\
& Type B & 14 & 27.5 \\
& Type C & 33 & 64.7 \\
\hline \multirow{5}{*}{ Soil condition } & Soil had been previously disturbed & 29 & 36.3 \\
& Unstable soil & 28 & 35.0 \\
& Wet conditions & 17 & 21.3 \\
& Frozen soil & 6 & 7.5 \\
\hline
\end{tabular}




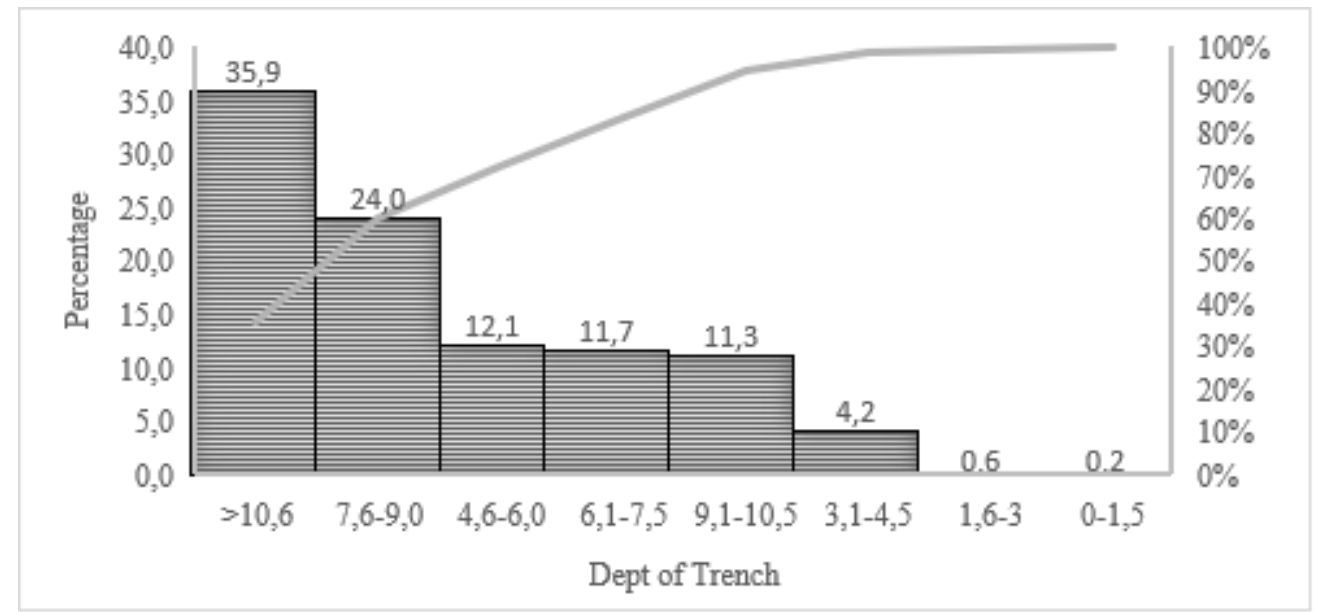

Figure 4. Dept of trench (ft).

Accidents result with the serious consequences not only with fatalities and injuries but also penalty fines. Citations inform the employer and employees of regulations and standards alleged to have been violated and the proposed length of time set for their abatement. Violations are also one of the techniques OSHA uses to convince or help force companies into compliance (Wagner, 2004). As a result of accidents, employers pay penalties at high rates based on the violations they have committed. OSHA citations and penalties are issued based on the nature and severity of the violation. A total of 2596 violations, including four main categories, were detected for 723 accident reports. Employers have paid approximately 23 million in penalties (Figure 5). CPWR (2018) also indicated that more than half (54\%) of the citations issued in heavy and civil engineering construction (NAICS 237) were violations of the OSHA trenching standards, a higher proportion than any other construction subsector.
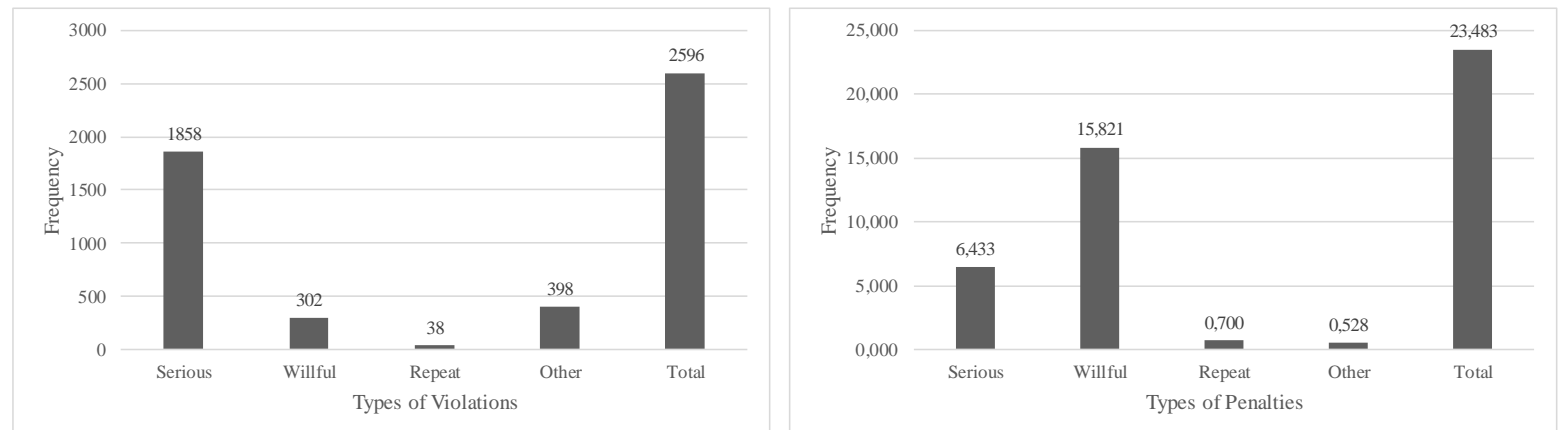

Figure 5. Types of violations and penalties $(\$ \mathrm{M} \$)$.

\section{Conclusions}

In this study, 723 occupational accidents that occurred because of trench collapse in the U.S. between 1995 and 2020 were investigated to understand the causes of trench collapse accidents associated with trenching operations and develop intervention strategies to identify the causes of trench collapse accidents. Statistical analysis reveals the importance and seriousness of occupational safety in excavation work. The study findings show that $58.1 \%$ of occupational accidents caused by trench collapse resulted in death.

An unprotected trench is the main reason for accidents for workers who dig or excavate trenches. According to accident investigations, the most important point to be noted is the lack of protective systems. Safety precaution was not provided in a majority of the cases. OSHA's excavation standard requires employers to provide sloping (or benching), shoring, or shielding to protect employees in excavations 5 feet or more in depth (Boom, 1999). Trenches 20 feet deep or greater require a protective system designed by a registered professional engineer. In deeper excavations, although walls are supported, emergency exits 
must be provided (Oglesby, 1989). Moreover, NIOSH recommended that the shoring or sloping of trenches deeper than 24 feet be determined by an engineer (Suruda, 2002). Workers should never enter a trench that does not have a protective system in place designed and installed by a competent person.

A competent person is an individual who can identify existing and predictable hazards or working conditions that are hazardous, unsanitary, or dangerous to workers; soil types; and protective systems required. The competent person is also authorized to take prompt corrective measures to eliminate these hazards and conditions. The competent person should be trained and designated to ensure safety measures in the excavation site. The competent person should evaluate the type of soil to determine its stability before excavation works start. A type of protective system should be decided afterward. The excavation, adjacent areas, and the protective systems should be inspected routinely each day before the start of work. Besides, inspection should be done as needed throughout the shift and specifically after every rainstorm. The competent person must remove workers from the excavation upon any evidence of a situation that could cause a cave-in, such as accumulation of water in the trench or protective system problems. Researchers have suggested that fatal events which occurred during the study period because of trench collapse could have easily been prevented if a competent person on site had followed OSHA regulations (Deatherage, 2004).

For trenching operations, employees need to be trained in the safety of trenches, their hazards, and all the regulations required by OSHA (Wagner, 2004). Training should be regulated in a language that workers understand and at the appropriate literacy level (Lopez-Arquillos et al., 2019). Workers should be warned about not entering an unprotected trench, inspecting the protected trench before entering and exiting the trench, and calling the competent person in case of any evidence of a problem with a protective system.

Moreover, employers pay high penalties for violations they committed because of occupational accidents resulting in deaths and injuries. Employers have paid approximately 23 million dollars for 2596 violations for the accidents examined within the scope of the study.

In summary, to prevent trench collapses, safety should be ensured when entering and exiting the trench, cave-in protection must be supplied, materials should be kept away from the edge of the trench, water accumulation and other hazards should be controlled, and entering improperly inspected trenches should be prevented. Moreover, exposure to falling loads should be prevented, employees should be protected from being injured or killed by vehicles, warning systems for mobile equipment should be used, atmospheric measurements should be made, and a trench emergency action plan should be developed. Besides, discussing what can be done to reduce the frequency and severity of accidents by taking lessons from past accidents in terms of the value of human life and the country's economy is necessary. OSHA's standard for excavation and trenching, known as “1926 Subpart P - Excavations," describes in detail the precautions needed for safe excavation work (OSHA, 2020b).

Author contributions: The sole author of this paper collected all dataset, did the analysis and interpretation, drafted the manuscript and approved the final version.

Funding: There is no funding.

Acknowledgments: Not applicable.

Conflicts of interest: The author declares that they have no competing interests.

References

ASH- Advanced Safety and Health. (2020). Most Frequently Cited OSHA Citations in Trench and Excavation Work - Revisited. https://advancedsafetyhealth.com/blog/frequently-cited-osha-citations-trench-excavation/ Accessed 1 November 2020.

Arboleda, C.A., \& Abraham, D.M. (2004). Fatalities in trenching operations-Analysis using models of accident causation. Journal of Construction Engineering and Management, 130, 273-280. 
BLS. (2010). Census of fatal occupational injuries (2000-2009). Washington, D.C. Bureau of Labor Statistics.

BLS. (2019). Census of fatal occupational injuries (CFOI) - Current and revised data. Washington, DC: U.S. Department of Labor, Bureau of Labor Statistics, https://www.bls.gov/iif/oshcfoi1.htm Accessed 16 May 2020.

Boom, J. (1999). Trenching is a dangerous and dirty business!. Job Safety \& Health Quarterly, 22-29.

CCOHS (Canadian Centre for Occupational Health and Safety). (2016). Trenching and Excavation. https://www.ccohs.ca/oshanswers/hsprograms/trenching_excavation.html Accessed 5 November 2020.

CPWR (Center for Construction Research and Training). (2018). The construction chart book (Sixth Edition).

Culver, C., Florczack, G., Castell, R., Connolly, C., \& Pelton, G. (1990). Analysis of construction fatalities-The OSHA database 1985-1989. Rep. Prepared for U.S. Department of Labor, Washington, D.C.

Deatherage, J.H., Furches, L.K., Radcliffe, M., Schriver, W.R., \& Wagner, J.P. (2004). Neglecting safety precautions may lead to trenching fatalities. American Journal of Industrial Medicine 45(6), 522-527.

Elcosh. (2020). Trench Collapse Hazard. http://elcosh.org/video/3790/a000088/trench-collapse-hazard.html Accessed: 16 October 2020.

Fenn, P., \& Ashby, S. (2004). Workplace risk, establishment size and union density. British Journal of Industrial Relations, 42 (3), $461-480$.

Flynn, M.A., \& Sampson, J.M. (2012). Trench safety-Using a Qualitative approach to understand barriers and develop strategies to improve trenching practices. International Journal of Construction Education and Research, 8:63-79.

Forteza, F.J., Carretero-Gomez, J.M., \& Sese, A. (2020). Safety in the construction industry: accidents and precursors. Revista de la Construcción. Journal of Construction, 19(2).

Gillen, M., Baltz, D., Gassel, M., Kirsch, L., \& Vaccaro D. (2002). Perceived safety climate, job demands, and coworker support among union and nonunion injured construction workers. Journal of Safety Research, 33 (1), 33-51.

Goldenhar, L., Williams, L.J., \& Swanson G.N. (2003). Modelling relationships between job stressors and injury and near-miss outcomes for construction labourers. Work Stress, 17 (3), 218-240.

Hinze, J., \& Bren, K. (1997). Causes of trenching related fatalities and injuries. Construction Congress V: Managing Engineered Construction in Expanding Global Markets, ASCE, Reston, Va., 389-398.

Hinze, J., Pedersen, C., \& Fredley, J. (1998). Identifying root causes of construction industries. Journal of Construction Engineering and Management, 124:67-71.

Hinze, J. (2005). Use of Trench Boxes for Worker Protection, Journal of construction engineering and management, 131, 494-500.

Hinze, J., Huang, X., \& Terry, L. (2005). The Nature of struck-by accidents. Journal of Construction Engineering and Management, 131(2), $262-268$.

Jannadi, A.A. (2007). Risks associated with trenching works in Saudi Arabia. Building and Environment, 43, 776-781.

Lan, A., \& Daigle, R. (2009). Review of Regulations and guides for excavation and trenches-comparison with the québec safety code for the construction industry. Practice Periodical on Structural Design and Construction, 14:201-209.

Le, A.B., Wong, S.W., Lin, H.C., \& Smith, T.D. (2021). The association between union membership and perceptions of safety climate among US adult workers. Safety Science 133, 105024.

Lee, S.Y. (2003). Simulation analysis of accident delays in utility trenching operations. KSCE Journal of Civil Engineering, 7(2), 107-113.

Lew, J., Abraham, D., Wirahadikusumah, R., Irizarry, J., \& Arboleda, C. (2002). Excavation and trenching safety: existing standards and challenges. Implement. Safety Health Construct. Sites, CIB.

Laborer's Health and Safety Fund of North America. (2020). Trenches and Excavations. https://www.lhsfna.org/index.cfm/occupational-safety-andhealth/trenches-and-excavations/ Accessed 15 November 2020.

Lopez-Arquillos, A., Pardo-Ferreira, M., Gibb, A., \& Rubio-Romero, J.C. (2019). Occupational safety needs into construction formwork market: Perception of stakeholders. Journal of Construction, 18 (1).

McCann, M. (2006). Heavy equipment and truck-related deaths on excavation work sites. Journal of Safety Research, 37, 511-517.

MMWR. (2004). Occupational fatalities during trenching and excavation work-United States, 1992-2001. Morbidity and Mortality Weekly Report-April 23, Center for Disease Control and Prevention, Atlanta.

Oglesby, C.H., Parker, H.W., \& Howell, G.A. (1989). Productivity improvement in construction. New York, USA: McGraw-Hill.

OSHA (Occupational Safety and Health Administration) (2020). Trenching and Excavation. https://www.osha.gov/trenching-excavation Accessed 16 November 2020. 
OSHA, (Occupational Safety and Health Administration) (2020b). 1926 Subpart P-Subpart P-Excavations. https://www.osha.gov/lawsregs/regulations/standardnumber/1926/1926SubpartP Accessed 12 November 2020.

Plog B.A., Materna, B., Vannoy, J., \& Gillen, M. (2006). Strategies to prevent trenching-related injuries and deaths, The Center to Protect Workers' Rights. https://www.cpwr.com/wp-content/uploads/publications/krtrenching.pdf Accessed 15 November 2020.

Rampuri, S. (2019). Excavation \& Trenching work Safety: A Review. International Journal of Institution of Safety, 2(2), 6-9.

Ruttenberg, R., Schneider, S., \& Obando, M. (2019). Recent trenching fatalities: causes and ways to reduce. CPWR, The Center for Construction Research and Training.

Schriver, W.R., \& Schoenbaum, M. (2003). Analysis of fatal events in the construction industry, 1991-2001: What do OSHA data show. Proceedings of the national occupational injury research symposium, National Institute of Occupational Health and Safety, October 29, 2003, Sites, May 7-10, 2002, Hong Kong.

Suruda A., Whitaker, B., Bloswick, D., Philips, P., \& Sesek, R. (2002). Impact of the OSHA trench and excavation standard on fatal injury in the construction industry. Journal of Occupational and Environmental Medicine, 44: 902-905.

Suruda, A., Smith, G., \& Barker, S.P. (1988). Deaths from trench cave-in in the construction industry. Journal of Occupational Medicine, 30 (7), $552-555$.

Thwala, W.D., Mustapha, Z., \& Aigbavboa, C. (2018). Management of health and safety risk associated with excavation cave-in. Proceedings of the International Conference on Industrial Engineering and Operations Management Washington DC, USA, September 27-29.

Wagner, J. P. (2004). Causal Analysis of Fatal Trenching Accidents, Master's Thesis, University of Tennessee, Knoxville. 